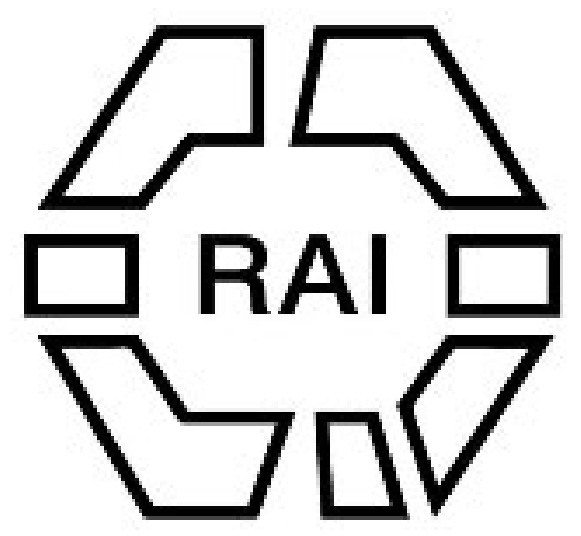

[Extracts Regarding the Inhabitants of Tristan d'Acunha] Author(s): N. Digby and G. S. Bosanquet

Source: The Journal of the Anthropological Institute of Great Britain and Ireland, Vol. 6 (1877), pp. 338-343

Published by: Royal Anthropological Institute of Great Britain and Ireland

Stable URL: http://www.jstor.org/stable/2841425

Accessed: 15/06/2014 19:19

Your use of the JSTOR archive indicates your acceptance of the Terms \& Conditions of Use, available at http://www.jstor.org/page/info/about/policies/terms.jsp

JSTOR is a not-for-profit service that helps scholars, researchers, and students discover, use, and build upon a wide range of content in a trusted digital archive. We use information technology and tools to increase productivity and facilitate new forms of scholarship. For more information about JSTOR, please contact support@jstor.org.

Royal Anthropological Institute of Great Britain and Ireland is collaborating with JSTOR to digitize, preserve and extend access to The Journal of the Anthropological Institute of Great Britain and Ireland. 
in to the shore, canoes came about us, eager, vociferous, and friendly, and with a rather villainous look. They are big compared to some other islanders about here, are not at all dark, some being very light, and with very light hair; but betel-nut chewing is universal. All mouths are full of a chocolate and black masticated mass, and teeth are as black as jet, with great lumps of the lime with which they chew the betel adhering as "tartar" to their teeth.

The following Extract is from a REPoRT on the IstaNd of Tristan D'Acunha, presented to Parliament in 1876 :

The Tristan d'Acunha group was originally discovered by the Portuguese (and named after the commander of the expedition) in 1506. It was further explored and described by the Dutch in 1643, and the French in 1767. From 1790 to 1811 the large island appears to have been occupied by American sealers. They appeared to have subsequently abandoned it ; for formal possession was taken in the name of the British Government by a small military force from the Cape of Good Hope, as an official notice of 30th March, 1817, announced the occupation. The object in occupying the island by a small detachment of artillery was the confinement of Napoleon Bonaparte at the time in St. Helena. At his death, in 1821, the detachment was withdrawn; but one of the party, Corporal Glass, and two seamen of the St. Helena naval squadron (which latter occasionally visited the island) obtained leave to remain. Glass became the recognised chief. He raised a large family; so also the two man-of-war's men. This and the immigration of a few whaling men, who married the daughters of the above, have brought about the present population. The group has been occasionally visited since 1821 ; the most notable of these visits was that made by the Duke of Edinburgh, in her Majesty's ship "Galatea," in August, 1867.

Commander N. Digby, R.N., on Jan. 8th, 1875, reported as follows:-

There are fourteen families on the island, eighty-five persons in all. They subsist on the produce of their farms, on which they rear cattle, sheep, pigs, and poultry, in considerable numbers, and cultivate potatoes and other vegetables. The sea abounds with fish, and the neighbouring islands are visited for seals. There is no lack of the necessaries of life, but as there is no regular communication with the rest of the world, they are dependent on the casual visits of vessels for clothing and luxuries. Want of flour is their most serious inconvenience, and wheat will not grow. The number of vessels calling there has considerably diminished since the American war, before which the island was frequently visited by American whalers, which are now but seldom seen. Peter Green, a native of Rotterdam, who was wrecked on the island about forty years ago, is the person who appears to have the greatest influence among the people, who are nominally on a footing of equality, and 
I believe it is due to his superior intelligence, aided by the advantage he possesses in point of age, that order is maintained. Green considers himself under the jurisdiction of Cape Town, and bases his assumption on the fact that, some years ago, Bishop Gray, of Cape Town, visited them, and made them sign a document acknowledging themselves in his diocese. Fresh provisions can always be obtained, of good quality, and in any quantity, and the boats are rarely prevented by stress of weather from commu. nicating.

On October 15th, 1875, Captain G. S. Bosanquet, R.N., made the following report on his visit to the island on the 12th and 13th October :-

The report made by Commander Digby, of Her Majesty's ship "Sappho," in January, represented accurately the state of this minute colony, and I have little of any value to add to it. I enclose a census of the population which I caused to be taken, from which it will be seen that there are only fifteen males of the age of twenty-one years and upwards. These represent the physical force, and I think I may also say the intellectual, of this somewhat unsophisticated community, although I should not venture to assert this (superiority of the males) of any more highly civilised one.

The families are connected by the ties of marriage, and their interests are identical. They have certain rules of their own, and the present senior male member of the community, Peter Green, is made their referee if necessary. This position has been conceded to him, not alone from his superiority in years, but also from having greater force of character, being a European, than the rest of the community, who are half-castes, and of more plastic materials.

There are two exceptions, one an Englishman, who came here some years ago from the Cape, and married, who is now desirous of leaving with his family, and going to New Zealand, or first to the Cape of Good Hope, and the other an American, who settled here of his own choice in 1845. The first of these, Joseph Beetham, I was willing to have removed to the Cape, as he evidently was dissatisfied, and is probably a disturbing element in the settlement; unfortunately, the principal female member of the family was not in a condition to make a hasty move.

It will be well, perhaps, to give a general account of the condition of the island, although, probably, Her Majesty's Government is well informed of all the facts of the case. The island, imposing, but gloomy and forbidding when seen from a distance, is volcanic, rising precipitously in almost all quarters from the sea in a continuous and magnificent chain of heights of from about 2,500 to 3,000 feet, furrowed by water-courses and ravines, and clothed with scrub and a specimen of dwarf pine; within this first barrier rises the great peak, said to be 7,640 feet high. On the north-west extreme there is a considerable tract of fertile undulating land, principally pasture, which slopes gradually to the low cliffs on the margin of the sea. The settlement is on the northern extreme of 
this tract, which is not the most eligible in point of shelter, but is convenient on account of the anchorage near by.

In the immediate vicinity of the settlement are several hundreds of acres of pasture land, on which feed numerous draught cattle, as well as sheep and pigs. The soil is rich here, but on account of the extraordinary violence of the winds at certain times it is almost impossible to grow anything, and many cattle at times have been killed by the actual force of the wind. Two years ago more than 100 milch cows were so lost during a violent north-easter. This part was also at one time covered with trees, as far as I can ascertain, of the same species as still exists on the heights, a sort of dwarf pine, low and twisted in their stems; these were entirely destroyed some years ago by a species of louse or beetle which seized upon the trunks.

About two miles south-west of the settlement there is a sloping grass plain of several thousand acres in extent, which is used in common as the grazing ground for all the cattle of the community, although the cattle themselves are the property of different owners. Small portions of this tract are fenced off for the cultivation of vegetables, and sheltered spots, formed by depressions in the ground, are planted with fruit-trees. Any quantity of the land could be brought under cultivation, but there is no means of disposing of the produce, as they did formerly, when numerous whalers frequented the sea around the island. The cattle amount now to about 400 head, since the severe loss mentioned above. There are many more sheep, and numerous pigs. The inhabitants live on their stock and other produce of the farms. Unfortunately for them, they have given up the cultivation of corn, which at one time grew abundantly, the reason being that the crops were destroyed by mice, which now infest the island, and no efficient steps have been taken to overcome this plague. In consequence of this the community are dependent for flour on ships calling. There is an abundance of good fish, such as rock cod, sea perch, cavalli, and great numbers were caught from the ship during our stay. At one time the island was frequented by seals and goats, but the former always migrate from the places where man settles, and the latter suddenly disappeared. Some time ago a number of goats were brought over from Inaccessible Island, where they are numerous, but these also disappeared as the others, and no trace of them has been discovered.

Within a few hundred yards of the shore a floating belt of kelp sea-weed, of considerable breadth, moored to the bottom, encircles the island. This is used for manure. Sometimes it is cut from boats, and sometimes great quantities are thrown upon the shore by the storms. Expeditions from the island are made at times to Inaccessible Island, for the purpose of procuring seals and sea elephants - the latter for the sake of the oil-also for goats and wild pigs.

Commander Digby states that the emigration of some of the community will be necessary as the population increases. I cannot see the necessity for this, although, for the comfort of the community, 
it may be best. I inspected the land, and made close inquiries, and there is land enough and stock enough for a very much larger number of people. I have little doubt that the peculiar enjoyment and content of the original few settlers has now to a great extent diminished., It depended on ample space, and abundance, and undisturbed possession; also this and the neighbouring islands and sea.abounded with seals, sea elephants, and wild goats, which were easily taken, and in very large numbers; and there was an extensive traffic for the few with the whale ships which then constantly communicated. With the increase of the inhabitants, however, their unbounded freedom was curtailed, as there were more people who had claims to be respected; there were more mouths to feed, and more hands to take part in the seal-hunting, \&c., and to share in the traffic ensuing therefrom. The wild animals just mentioned became more scarce, the supply of seal-skin and sea elephant oil falling off, ships ceased almost entirely to visit the island.

The present community are naturally averse from any influx of settlers, as it would increase the drawback mentioned, and steadily reduce what seems to me to be the only attraction to the place, viz., space, and plenty on sea and land, all at their own disposal, with few to participate, and those mostly united by family ties. There is also another and an increasing difficulty-that of obtaining certain necessaries, such as clothing, blankets, flour, and groceries. These used to be obtained by barter from the whale ships, which also purchased the skins, oil, \&c., and obtained supplies of beef and vegetables; but as the whale ships scarcely ever now visit the island, the people are in a worse position than formerly, and poorer, as they have no incentive to raise a larger quantity of food, there being no longer a demand for it. Their possession of a small vessel to carry the produce and cattle to the Cape could be of no use, as there is no safe anchorage. Firewood is procured from the scrub and small trees which grow on the heights.

The Governor of the Cape of Good Hope makes mention in his letter to the Colonial Office of the alleged inhospitable treatment by the islanders of people resorting there for fishing and other purposes. I do not think the community deserve this. They are, doubtless, anxious on the score of others coming there, simply on account of the difficulty of keeping themselves even indifferently supplied with certain necessaries, such as clothing and flour, and luxuries, such as tea, sugar, and tobacco ; but many ships have been wrecked or abandoned off this island, and the crews have been well cared for by the community, who have received little or no return for it; and I may here remark that, from the statements of one or two of these people as to some of the ships burnt, wrecked, or abandoned near this island, although it does not appear to have occurred to them that a suspicion was unavoidable that this neighbourhood was taken advantage of for the iniquitous purpose of destroying ships when the crew could be saved, where no judicial investigation could take place, and from which evidence could not be easily procured. 
Peter Green informed me that there is land as extensive and equally good on the south side of the island, and much the same sort of anchorage, but the wind commonly prevailing, which is westerly, blows on to the shore. It is possible to get round to it on foot, but it is difficult, and cattle could not be transferred there by land without a track being made. Education is doubtless at a low ebb. Some few children are taught by Peter Green and his wife, and some others by Mrs. Frances Cotton. Most of the people can read, but many cannot write. There is a fair supply of Bibles, and some school-books, but an additional supply of both is needed, as well as of slates, \&c.

The community could not find a salary for a schoolmaster, but they would be ready to supply him with food. A clergyman or Scripture reader (the Rev. William F. Taylor) resided in the island when it was under the see of Cape Town, from 1850 to 1856. When he left, he induced more than half the inhabitants (forty-five in number) to leave with him for the Cape. I understand that he was paid by some society or individual in England, but the community supplied him with food.

Several of the present islanders have been away at times whaling, or on visits to the Cape Colony or St. Helena; one or two of the women also have been in service at the former place, but, finding the wages not sufficiently remunerative, returned to the island. As I have previously stated, there is no means of establishing a communication by private vessels, as they have almost entirely ceased to touch there; even when these visits were frequent, they were made almost entirely by outward-bound ships, whether whalers or others; the former were generally en route for New Zealand, but none touched at the Cape. The only dependable communication must be by men-of-war, as mentioned by me in the suggestions for the future rules and laws.

The chaplain of this ship, the Rev. John Pitman, baptised twentyfive children, one of which was born the night after our arrival. The remaining unmarried daughter of Peter Green, and the only young lady of sufficient age at this time, was married to one of the community by him also. I had the pleasure of witnessing the ceremony with several other officers of this ship, and afterwards we were entertained at a repast by our host, the bride's father, in a most sumptuous manner. All the community took part at the feast, and we were all astonished, not only at the lavish abundance, but at the excellence of the cuisine.

The arrival of a ship is the signal for a holiday, as in this instance, and I was much struck by the cleanliness and neat appearance of all; but the most pleasing feature was the quiet and unaffectedly good manners of the community, perhaps more particularly amongst the women and younger ones.

I assembled the elders of the community to confer with, and informed them of the object of my visit and the views of Her Majesty's Government. They did not apparently see the necessity for any rules of government, but they desired that there should be 
some constituted authority in order to prevent the occurrence of such an infliction as occurred during the late American war, when the "Shenandoah" landed some forty prisoners without providing for them, and when the captain of the ship was remonstrated with, and told that the island was under the jurisdiction of Caps Town, he desired them to show him some document to prove it. The unanimous desire and first requirement of the people is for a resident minister, and if such cannot be had, for a schoolmaster or Scripture reader. They could not provide him with an adequate salary, as they are too poor, more so than formerly, but they would furnish him with food, as they did to the Rev. W. Taylor. If such a minister could be provided, having also sufficient intelligence and energy as to direct the inhabitants in the improvement of their land, by planting, raising stone walls to shelter the crops, and reintroduce the cultivation of corn, protecting their crops by a judicious system of deep overhanging trenches, or any other means, to guard them from the ravages of mice, it would be a very great benefit to them.

\section{NEW ZEALAND HEAVEN AND EARTH MYTH.}

The following version of the New Zealand myth of the creation has been communicated by Mr. J. F. H. WoHLERS :-

The name of the oldest god was Tangaroa. He was the uncle of Heaven (Rangi) and the first husband of the Earth, whose personal name as a woman was Papatuanuku. Once, when Tangaroa was absent, Heaven took his wife, the Earth. When Tangaroa came back Heaven had to meet him in a duel for the offence, and was by him wounded and lamed for ever. Tangaroa, having had satisfaction, left the Earth, and she was thenceforth -Heaven's wife. The latter being lamed, could not stand upright. Heaven was then laying flat on the earth, and it was close and dark on the same; no wind could blow, no light could shine. Still Heaven and Earth brought forth many children; most of them were cripples, but a few had sound limbs. Among the latter was Tane, the most conspicuous. The children found the close darkness inconvenient, and had a consultation what to do to gain light and liberty. Some proposed to kill their father, Heaven, and to be content with one parent, their mother, Earth. Others advised to lift Heaven up high above, and there let him remain a stranger to them. This was agreed to. After much exertion, Heaven was lifted and carried up by his children, and fastened by Tane. When Tane came down again he looked up to his father, but the old man looked dark and sad. So Tane went and fetched ornaments, with which he gave Heaven a bright polish. Then, when he came down again, and looked up, he thought his father was not yet ornamented as he ought to be, so he got more ornaments, of which he drew the milky way and set the constellations. Then he came down and looked at wha the had made, and it was good. Now Tane looked at his mother, the

VOL. VI.

B B 